\title{
第37回日本老年医学会学術集会 一般演題（VI）
}

座長: 馬場 忠雄, 深沢 俊男, 鎌田 武信, 高橋 忠雄, 南野 壽重, 吉田 亮一

288. 高跉者の上部消化管疾患における $\boldsymbol{H}$. pylori の関与について

埼玉医科大学第三内科

矢部 諭, 岩堀 泰基, 吉田 典子

西山 淳一, 西島 樹重, 西蔵ツワン

中島 俊之, 佐々木一圭, 藤原 研司

目的: 近年, 胃炎, 胃 -十二指腸潰瑒, 胃癌の発生 に H. pylori (以下 HP) の関与が示唆されている. そ こで, 今回, 高齢者における, 上部消化管疾患と HP と の関わりについて検討した。

対象：内視鏡検査により, HP 感染の有無が判明し た60歳以上の患者73名 (男女比48：25) を対象とした。 内訳は胃・十二指腸潰瘍 (GU/DU) 30例, 萎縮性胃炎 (AG) 22例, 胃癌 (GC) 9 例, 胃癌発生低リスク群と される胃稜線状発赤・胃底腺ポリープ (KR/FGP) 9 例，その他 3 例である.

方法：(1) HP 感染の有無は, 内視鏡検査時に, 幽門 前庭部小彎および胃体中部大彎より生検を行い Gram 染色（後染色に Pfeiffer 液を使用）による検鏡法によ り行った。(2)53名については, UBI MAGIWEL キッ トを用いて抗 HP IgG 抗体を測定した。

結果：(1)検鏡法による HP 陽性率は GU/DU 群30/ 30 (100\%), AG 群15/22 (68\%), GC 群6/9 (67\%), KR/FGP 群 $0 / 9$ ( $0 \%$ ) であった. (2) AG 群では HP 陰 性であった 7 例中 5 例について抗 HP IgG 抗体を測定 した。その結果，抗体陰性例は 1 例のみであった. (3) $\mathrm{KR} / \mathrm{FGP}$ 群で抗 HP IgG 抗体を測定しえたのは 4 例 で，いずれも陰性であった. (4)再発を繰り返していた GU/DU 群の 6 例について除菌療法を行い，3 例で除 菌に成功した。

結論：高齢者の上部消化管疾患において, HP は, 胃・十二指腸潰瘍, 萎縮性胃炎, 胃癌に関与している と推定された。

289. 胃癌及び消化性潰瘍患者における抗 Helicobacter pylori 抗体価と加齢の関連

東海大学内科六

甲田 勝昭, 白井 孝之, 車田 知之 太田 有紀，小林 寛久，高木 敦司

\section{原澤 茂, 三輪 剛}

Helicobacter pylori (H. pylori) は胃炎, 消化性潰 瘍の主因の 1 つとされつつある。慢性萎縮性胃炎は胃 癌の発生母地として認識されていることょり胃癌と H. pylori の関連が注目を集めているが, 疾患別による 差異さらに加齢による変化については充分検討されて いない. 今回我々は血清診断法を用いて抗 H. pylori 抗体価と胃癌, 消化性潰瘍の加齢による関連を検討し た。

胃癌患者84例（24歳～84歳平均50.1歳）及び消化性 潰瘍患者33例（22歳～67歳平均43.9歳）において空腹 時血清を用いた ELISA 法による抗 H. pylori-IgG 抗 体キット (QUIDEL 社製)を用いて抗体価を測定した。 抗体価の判定域 $36 \mu / \mathrm{m} l$ 以上を陽性, $24 \mu / \mathrm{m} l$ 末満を 陰性, 両者の中間は判定保留域とした. 胃癌患者群で は83\%が陽性, 消化性潰瘍患者群は全例陽性であった。 各群を年代別に分け比較検討したところ, 同一疾患内 では胃癌患者群, 消化性潰瘍群とも各年代による明確 な有意差は見られず，加齢の影響は乏しいものと思わ れたが, 両疾患群の 40 代, 50 代においては胃癌患者群 が消化性潰瘍群に比し(40代127.4：95.8,50代116.8： 90.9）とやや高い傾向がみられた。更に症例を増やし 検討中である。

\section{0. 老年者胃潰瘍における胃内逆流タウロコール酸} 一胃粘膜性状, Helicobacter pylori 感染との関連性 日本医大内視鏡科 ${ }^{1}$, 病理部 ${ }^{21}$

松久 威史 ${ }^{1)}$ 山田 宣孝 ${ }^{21}$

胃内に逆流した胆汁酸中の夕ウロコール酸は胃粘膜 の萎縮に影響を及ぼすと言われている。60歳以上の老 年者胃潰瘍例における逆流夕ウロコール酸と内視鏡的 胃粘膜性状の関連性を胃粘膜萎縮の観点より検討し た. その際, タウロコール酸の定量は HPLC 法により 行った。

老年者胃潰瘍 24 症例中夕ウロコール酸の逆流が確認

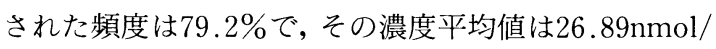
$\mathrm{m} l$ であった。逆流頻度を年齢層別にみると, 40 歳末満 の若年者 $(8$ 例中 $87.5 \%), 40$ 歳以上 60 歳未満の壮年者 (48例中 $83.3 \%$ )の間に有意差はみられなかった.一方, 
タウロコール酸濃度は若, 壮年者 (各々 $74.88 \mathrm{nmol} /$ $\mathrm{m} l, 33.92 \mathrm{nmol} / \mathrm{m} l)$ に比し老年者において低く $(26.89 \mathrm{nmol} / \mathrm{m} l)$, 加柃と共に濃度の低下する傾向が うかがえた。

タウロコール酸濃度と胃粘膜性状の関係について は，胃体下部小彎側の血管透見像の有無により 5 段階 に分類されている大島の基準を使用した。老年者胃潰 瘍のうち萎縮性胃炎を伴わない例に比しそれを伴う例 (血管透見群)に扔いてタウロコール酸の逆流頻度が高 かった（萎縮性胃炎合併例：14例中 $85.7 \%$ ，萎縮のな い例：10例中 $70.0 \%)$ ここれは他の年齢層においても類 似していた。また，萎縮性胃炎を合併した老年者胃潰 瘍のタウロコール酸濃度もそれを合併していない老年 者胃潰瘍に比し高い傾向にあった（萎縮合併：29.50 $\mathrm{nmol} / \mathrm{m} l, \mathrm{~N}=14$, 萎縮なし $: 23.25 \mathrm{nmol} / \mathrm{m} l, \mathrm{~N}=$ 10).この成績は若,壮年者においても同様であったが, 若, 壮年者に比し低値であった。この事実よりタウロ コール酸濃度よりもタウロコール酸の胃内への長期間 にわたる逆流が胃粘膜萎縮の一因となっているものと 思われた。

胃潰瘍例の Helicobacter pylori 感染率は壮年者およ び軽度, 中等度萎縮群において高く老年者および高度 萎縮群において低かった. Helicobacter pylori に対し て除菌的に作用することが知られている胆汁酸中のケ ノデオキシコール酸, ウルソデオキシコール酸と Helicobacter pylori 感染率の間には明らかな関連性は みられなかった。

\section{1. 加齢による Helicobacter pylori (HP) の除菌} 率低下についての検討

東京女子医科大付属成人医学センター

秋本真寿美, 橋本 洋, 新見 晶子
北村 容子, 渡辺 七六, 石川 雅枝
前田 淳, 重本 六男, 山下 克子
横山 泉

加齢と除菌率の関係を検討した。

対象と方法：30〜 78歳の52例. 使用薬剤は, ランソ

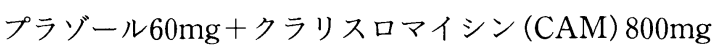
を 2 週間。疾患は胃潰瘍 14 例, 胃十二指腸潰瘍 21 例, 十二指腸潰瘍 12 例, 胃炎 5 例である。除菌判定は除菌 療法終了後 $4 \sim 6$ 週後に内視鏡検査にて培養・CLO test・鏡検を行うと共に, 同日の内視鏡検查前に ${ }^{13} \mathrm{C}$-尿 素呼気テスト (UBT) を施行した。いずれも陰性を除 菌成功とし, UBT は 5 パーミル末満を陰性とした。ま
た, 除菌後の薬剤而性, 背景胃粘膜炎症反応 (MPO・ IL-8）の変化も検討した.

結果：1）検査法別除菌率：従来法の 3 法では, 30歳 代 $60 \% ， 40$ 歳 $75 \% ， 50$ 歳 $64 \% ， 60$ 歳 $75 \% ， 70$ 歳 $20 \%$. UBT では 30 歳 $60 \%, 40$ 歳 $38 \%, 50$ 歳 $36 \%, 60$ 歳 $17 \%$, 70 歳 $0 \%$ と加齢と共に低下した. 2) CAM 而性菌：除 菌不成功 14 例中, 40 歳代 5 例, 50 歳 3 例, 70 歳 1 例が 而性となった。除菌前（42例）は， CAM 而性例は 0 . 3）除菌後背景胃粘膜炎症反応の変化：除菌成功例で は IL-8は 8 例（73\%)，MPO は11例（100\%）改善し， 増悪例は 0 。除菌不成功例では IL-8は 3 例 (19\%), MPO は 6 例（38\%）増悪した。

結語：除菌判定法では, UBT が他の検査法に比べ HP の検出率が高く, 簡便で非侵襲性であり, 特に高齢 者に適していると思われた。除菌率は加齢と共に低下 したが，除菌前の薬剤耐性や胃粘膜の炎症反応に年齢 差は認めなかった。除菌不成功例で背景胃粘膜の炎症 が憎悪したり, 薬剤耐性となる例があり, 使用薬剤・ 投与量・投与方法など除菌療法の適応は慎重な検討を 要する.

\section{2. 高齢者潰瘍性大腸炎の臨床的, 内視鏡的検討} 滋賀医科大学第二内科

矩 照幸, 松本 啓一, 塩見 毅彦 佐々木雅也, 小山 茂樹, 吉岡うた子 井上 久行, 藤山 佳秀, 馬場 忠雄

はじめに：潰貆性大腸炎 (以下 UC) の好発年齢は 20 歳台に多く, 日常診療において65歳以上の高齢者に発 症することは比較的少ない。そのため，時として診断 が遅れることがある.

目的：今回我々は，高齢発症 UC の内視鏡像から高 齢者 UC の臨床的特徵を明らかにし, 若年 UC との診 断，治療の差異を検討した。

対象：当院で 2 回以上, 大腸内視鏡検査が施行され, 内視鏡的に経過観察のできた UC 74例のうち，65歳以 上発症の UC 7 例と 20 歳以下の若年 UC 16例を比較検 討した。

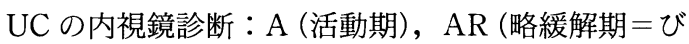
らん発赤が軽度で血管透見の回復の見られないもの), $\mathrm{R}$ (緩解期)。さらに活動期 $\mathrm{A}$ を比較的軽症の A1. 中 等症の A2. 重症の A3. また緩解期 $\mathrm{R}$ も内視鏡的に正 常粘膜と区別できない R0. 血管透見像は認めないが, 炎症所見がほぼ消失した R1. 炎症性ポリープと腸管変 形を共に認める R3とした。 
結果：病変範囲では直腸炎型 2 例 $(29 \%)$, 左側大腸 炎型 3 例 (42\%)，全大腸炎型 2 例 (29\%) で若年者 UC と比較して狭い傾向にあった。臨床的重症度は, 軽症 1 例 (15\%), 中等症 4 例 (57\%), 重症 2 例（29\%） で若年者 UC と差を認めなかった，病型分類は初回発 作型 5 例 $(71 \%)$, 再燃緩解型 1 例 (15\%), 急性電撃 型 1 例（15\%）であった。初回と最終内視鏡像より緩 解率を比較すると, 高齢者 UC では A2, A3の内視鏡的 な重症度が高いものでも治療によく反応し高い緩解率 を示した。

結語：1. 高齢発症では病変範囲は比較的狭い傾向 にあった。2. 臨床的重症度, 病型分類に大きな差はな かった.3. 高齢発症で内視鏡的および臨床的緩解率は 高い傾向にあった. 4. 急性電撃型での発症があった。

\section{3. 老年者における下部消化管出血症例の検討}

市立旭川病院内科

$$
\begin{aligned}
& \text { 北川 隆, 垂石 正樹, 相馬 光宏 } \\
& \text { 武藤 英二, 武田 章三 }
\end{aligned}
$$

目的：下部消化管出血は上部のそれに比べ一過性で 自然に止血することが多く，一般的には重症例が少な いとされている．しかし，老年者は何らかの基礎疾患 を有し，それが原因で発症することがあり，ときに急 性あるいは大量出血をきたす。そこで，65歳以上の老 年者の下部消化管出血に対する大腸内視鏡検査施行例 について検討した。

対象：下部消化管出血をタール便以外の血便を含め た明らかな䫓性出血に限定し，便潜血反応陽性例や先 に他の検查で診断された例は除外した。1994年 1 月か ら1995年 4 月までに下部消化管出血に対して大腸内視 鏡検査を施行した159例のうち, 老年者症例は57例で男 性24例, 女性33例, 平均年齢75.5歳（65歳～97歳）で ある。

結果: 疾患は虚血性大腸炎 (9 例), 痔疾 (9 例), 直腸・大腸癌 ( 8 例), 薬棛起因性腸炎 ( 7 例), 感染 症あるいは分類不能を含めたいわゆる腸炎（7例）の 順に多かった。不明例 6 例のうち 3 例は急性・大量出 血をきたし, 後日行った他の検査でも出血源が判明し なかった. 症状出現から 72 時間以内に大腸内視鏡検查 を施行した症例は36例 (63\%), 他科から紹介された症 例は32例（56\%）であり，大量出血例 9 例（16\%）に 対し緊急的に輸血が行われた。ほとんどの症例は何ら かの合併疾患を有し，さらに出血に関与する基礎疾患 もみられ, 高血圧, 不整脈, 狭心症, 糖尿病, 感染症
の順に多かった. とくに高齢者において, 愁訴がはっ きりしなかったり, 病状に対する反応が鈍かったりす るケースもみられた。

結論：下部消化管出血に対しては大腸内視鏡検査を 積極的に行い，速やかに診断することが望ましい。老 年者の場合, 若年者に比べ発症の仕方, 程度, 経過な ど, しばしば差異を認めることが多く，その特異性を 十分に把握することが重要である。

\section{4. 高齢者 $\mathrm{C}$ 型慢性肝疾患の検討}

和歌山県立医科大学附属紀北分院内科

佐藤 博明, 佐藤裕美子

船迫 真人, 大畑 雅洋

C 型慢性肝疾患については感染時期の長期化にとも ない進展するといわ机一方ウイルスタイプ, ウイル ス量の差により進行に違いがあり高齢者でも進展して いない症例があることが報告されている。今回我々は 60歳以上（高齢群）の C 型慢性肝疾患患者についてウ イルスタイプ, ウイルス量 (DNA-プローブ法), 組織 進展の評価として肝線維化マーカー (PIIIP, IV 型コ ラーゲン7S）さらにインターフェロン治療効果を60歳 末満（若年群）と比較検討した。

対象および方法：当院外来にて定期的にフォローし ている C 型慢性肝疾患患者 161 例 (高齢群 75 例, 若年群 86例)である.ウイルスタイプは岡本らの方法で $1 \sim 4$ 型に, ウイルス量はDNA-プローブ法で, PIIIP は Hoechst 社製 RIA-gnost PIIIP coated Tube, IV 型 コラーゲン7S は日本 DPCコーポレーション社製 RIA-kit を使用し測定した。

結果：ウイルスタイプについては 2 型, 3 型，4 型, の割合は高噛群 $61 \%, 35 \%, 4 \%$, 若年群 $56 \%, 38 \%$, $6 \%$ と両群間に差はなく, ウイルス量についても 0.50 未満, 0.5 以上 10 未満, 10 以上の割合は, 高齢群 $31 \%$, $42 \%, 27 \%$, 若年群 $27 \%, 49 \%, 24 \%$ と差を認めなかっ た。肝線維化マーカーでは, IV 型コラーゲン7S が高齢 群で $6.8 \pm 2.4 \mathrm{ng} / \mathrm{m} l$, 若年群 $5.9 \pm 1.9 \mathrm{ng} / \mathrm{m} l$ と高齢群 で高い傾向を示したが統計的有意差 $(\mathrm{p}=0.058)$ はな かった.また, PIIIP 值は高齢群 $1.21 \pm 0.42 \mathrm{U} / \mathrm{m} l$, 若 年群 $1.15 \pm 0.34 \mathrm{U} / \mathrm{m} l$ と有意差 $(\mathrm{p}=0.167)$ は認めな かった.インターフェロン治療は治療終了 6 力月以上 経過し効果判定可能な症例は高齢群25例, 55例であり GPT 正常化し HCV-RNA 陰性化した著効例の割合 は高齢群で $41 \%$, 若年群で $33 \%$ と差は認めなかった。 結語：今回の検討では高齢者に特徵的なウイルス夕 
イプはなく, ウイルス量も多くなかった。組織の進展 も肝線維化マーカーを指標とするかぎり明確な差は認 めず，60歳以上の患者でもインターフェロン治療が十 分有効な治療方法であると考えられた。

\section{5. 高齢者劇症肝不全及び遅発性肝不全：65歳以上 の高齢者剖検例と40歳以下の若年者剖検例の比較}

東京都老人医療センター病理部 ${ }^{11}$, 内科 ${ }^{2}$, 東 京医科歯科大学医学部病理学教室 ${ }^{3)}$

沢辺 元司 ${ }^{11}$ 田久保海誉 ${ }^{11}$ 江崎 行芳 ${ }^{11}$

深沢 俊男 ${ }^{21}$ 広川 勝昱 ${ }^{3)}$

65歳以上の高齢者劇症肝不全剖検例13例及び遅発性 肝不全 1 例について 40 歳以下の若年者対照群 10 例と臨 床病理学的に比較検討した. 高齢者群の臨床病型は劇 症肝不全急性型が 4 例, 劇症肝不全亜急性型が 9 例, 遅発性肝不全が 1 例であった。成因としては B 型が 3 例, 薬剤性が強く疑われた症例が 3 例, その他ウイル 不性と思われるが検索が不十分で特定できなかった症 例が 8 例であった。病理学的には劇症肝不全症例13例 の内11例が亜広汎性壊死，2 例が再生不良症候群で あった。亜広汎性壊死11例の内 9 例は典型的経過を 辿ったが，残り 2 例では臨床経過日数に対し肝細胞の 再生が不十分であった。遅発性肝不全の 1 例では肝細 胞の変性と脂肪化が目立った。一方, 若年者対照群は 劇症肝不全急性型が 3 例, 劇症肝不全亜急性型が 7 例 よりなり病理組織学的には急性広汎性壊死が 2 例, 亜 広沉性壊死が 8 例であり, 再生不良症候群は認められ なかった。若年者対照群に対し高齢者群では基礎疾患, 末期合併症の何れも高頻度に認められた．以上の結果 から高齢者群においては若年者対照群と同様の著しい 肝細胞壊死を示す典型的症例も見られたが，急性広範 性壊死の症例はなく, また再生不良症候群が少数例認 められた。 また亜広汎性壊死の 2 例と再生不良症候群 の 2 例では肝細胞再生が不良でありそのため肝不全が 遷延, 重症化したと思われた. 更に高齢者劇症肝不全 の予後が若年者対照群と比較し不良な原因として基礎 疾患，末期合併症の多い点が想定された。

\section{6. 高齢者の急性胆囊炎に対する経皮経肝的胆囊ド レナージの意義}

東京都老人医療センター外科 野呂 俊夫

目的: 高齢者の急性胆翼炎は穿孔の頻度が高く, 従 来しばしば緊急手術の対象となってきた. 超音波検査 器機の著しい進歩により, 今日では経皮経肝的胆囊ド
レナージ (PTGBD) が普及し, 当センターにおいても 平均年齢78.7歳の高齢者60例に本法を施行した. 高齢 者急性胆囊炎に対する本法の利点, 欠点などを明らか にするために, 手術による急性胆囊炎の治療と比較し た.

対象と方法：対象は男性34例, 女性26例, 計60例の 急性胆囊炎患者で年齢は61〜94歳, 平均78.7歳である. PTGBD は適当な右肋間を選び，局所麻酔下に 22 ゲー ジの外套つきの穿刺針で超音波誘導下に経肝的に胆囊 を穿刺し，針を抜いたあと，外套からカテーテルを胆 囊内に挿入し，カテーテルは皮膚に固定する.

結果：PTGBD 後60例全ての患者は臨床症状の著明 な改善を示し, 24〜48時間以内に自発痛, 圧痛, デファ ンスなどは消失ないし軽快し, 白血球数も正常化した. 胆汁中に一過性に血液が混入することがあるが，それ 以外には何の合併症も発生していない.

老年医学的意義：高齢者は肺, 心, 肝, 脳などに少 なくとも一つ以上の合併症を持っていることが多く, 脱水症状を伴いやすいので, 急性胆囊炎の緊急手術は 十分な術前処置の後でないとしばしば危険を伴う。麻 酔も必要となる。しかし PTGBD は手軽に, 短時間で 安全に施行でき, 急性胆霊炎の一次治療としては非常 に有益な方法であり, 症状の改善も著しい. 欠点の一 つはPTGBD 後ある程度炎症が治ってから手術を行 うので，入院期間が長くなり，入院費も高くなること である.また，PTGBD のみで胆囊摘出術を施行しな かった 3 例に急性胆囊炎の再発がみられ, 本法が急性 胆囊炎の根治にはつながらないことも挙げられる。し かし, 高齢, high risk の患者には意義ある治療法であ ることは明らかである。

\section{7. 高齢者における胆囊容積および収縮率に関する 臨床的検討}

名古屋市厚生院内科 ${ }^{11}$, 名古屋市立大学第一 内科 ${ }^{2}$

山田 尚史 ${ }^{1)}$ 山田 珠樹2) 早川 富博 ${ }^{2)}$ 宮治 真 ${ }^{2)}$ 武内 俊彦 ${ }^{21}$ 山本 俊幸 ${ }^{11}$

目的：加齢とともに胆石保有率が増加することが報 告されているが, 胆石の形成に影響を及ぼすと考えら れる胆襄の生理機能に関して臨床的に検討された報告 は少ない. 今回, 高齢者を対象に胆囊容積と収縮率を 腹部超音波装置で測定し, 加齢, 性別, 胆石の有無, 脳血管障害の既往 (CVD) の有無による影響について 検討した. 
方法：腹部超音波検査を施行した150名(男55名, 女 95 名, $60 \sim 116$ 歳, 平均年齢81.2歳) を対象として, 早 朝空腹時に胆襄容積を, 超音波診断装置 (アロカ SSD 1200)を用いて ellipsoid 法で測定した。収縮率は, infomed consent $の$ 得られた48名を対象に，セルトニン $(0.2 \mu \mathrm{g} / \mathrm{kg} \mathrm{BW})$ 筋注後, 経時的に胆噌容積を測定し て算定した。

結果：1）加齢に伴って体表面積が減少するので, 胆 囊容積を体表面積で除して補正すると, 胆囊容積/体表 面積比は, 加齢と共に増加する傾向がみられた. 2) 有 胆石患者で胆囊容積は有意に増加していたが, 性別, CVD の有無による差はみられなかった。 3）胆霊の収 縮率は, 80歳以上の高齢者で有意に増加していたが, 胆石, CVD の有無による有意の変化は認められなかっ た.4）収縮前の胆襄容積と胆囊の収縮率の間に有意の 正の相関がみられた。

老年医学的意義：今回の検討より, 胆囊の生理機能 が加齢に伴って変化することが明らかとなった。加齢 と胆石形成との関係は不明であるが, 部分的には, 加 齢に伴う変化によるものと考えられた。

\section{8. 膵炎の病態に及ぼす加齢の影響}

名古屋大学第二内科, 同 総合保健体育科学 センター

$$
\begin{aligned}
& \text { 北川 元二, 成瀬 達, 飯塚 直彦 } \\
& \text { 中江 康之, 近藤 孝晴, 早川 哲夫 }
\end{aligned}
$$

目的：高齢者では加龄による諸臓器の変化を背景に して膵炎の病態や経過が修飾される可能性がある.今 回は高齢者膵炎の特徵を知るために, 膵炎の病態に対 する加秢の影響を検討した。

方法：当科および関連施設で経験した急性膵炎 364 例, 慢性膵炎 452 例を対象に60歳以下と61歳以上の 2 群 に分けて, 膵炎の成因, 病態, 経過, 予後などについ て検討した。

結果：急性膵炎364例中61歳以上（134例）では成因 はアルコール性 $14 \%$, 胆石性 $51 \%$, 特発性 $31 \%$ とアル コール性が少なく, 胆石性が多かった。重症度, 臨床 検査成績など萃炎の病態に差はみられなかった。しか し, 重症急性膵炎74例の死亡率は60歳以下（42例）は 19\%であるのに対し，61歳以上（32例）では $59 \%$ と後 者が有意に高かった。慢性膵炎確診 (I) 群452例中61歳 以上（114例）では成因はアルコール性38\%, 特発性 $50 \%$, 胆石性 $10 \%$ とアルコール性が少なく, 特発性が 多かった. 疼痛は61歳以上で疼痛の程度が軽度である
ものが多かった．糖尿病の頻度は 61 歳以上が $41 \% ， 60$ 歳以下が $44 \%$ であったが，61歳以上ではインスリンを 必要とする症例が少なかった (24\%vs 48\%)。霊胞, 出血などの合併症の頻度, 程度は61歳以上で軽度な傾 向がみられた。

老年医学的意義：急性膵炎では重症化する割合は年 齢による差は認めないが，いつたん重症化すると，高 齢者ほど腎, 心, 肺, 肝などの臟器の潜在する機能低 下のために死亡率が高いと考えられる。慢性萃炎では 高齢者ほど病態が軽い傾向がみられるが，これは禁酒 が困難で症状の高度なアルコール性膵炎は50歳代の早 期に死亡することが多く, 一方で慢性膵炎の経過とし て加齢によって膵組織が脱落し（いわゆる burn out）, 症状が軽減するためと考えられる。

結論：高齢者では急性膵炎は予後が悪く, 慢性膵炎 では病態が軽度な傾向がある。

\section{9. 経皮的内視鏡下胃瘻設置術（PEG）の有用性に 関する検討}

東京大学医学部老年病学

片山 弘文, 大賀栄次郎, 須藤 英一

徐中宇, 長瀬 隆英, 松瀬 健

福地義之助, 大内 尉義

東京都老人医療センター

名倉 博史, 紀 健二
木田 厚瑞, 橋本 肇

目的：経口摄取不能症例の栄養摄取方法としての, 経皮的内視鏡下胃瘦設置術（PEG）の有用性について 検討した.

対象：1991年 9 月から1994年10月までに東京都老人 医療センターに入院した PEG 施行 30 例 (PEG 群) (平 均年齢 $77.3 \pm 1.6$ 歳, 平均観察期間 $477 \pm 50$ 日 ; mean士 S.E) と, 対照群の経鼻カテーテル栄養施行21例 (経鼻 カテ群) (平均年齢 $81.9 \pm 1.6$ 歳, 平均観察期間 $493 \pm 90$ 日).

方法：後乃向き調査で, (1) PEG, 経鼻カテーテル 栄養施行前後 1 力月間の発熱エピソード回数, 抗生剤 使用日数, (2) 両群施行前後 1 力月目の炎症反応 (WBC, CRP), (3) 栄養状態 (Alb, ChE), (4) 両群 間での予後比較，(5) PEG の在宅管理に関するアン ケート調查を行った.

結果：(1) 両群施行前後で, 発熱回数, 抗生剂使用 日数に有意な変化は認めなかった。（2）両群施行前後 で, WBC に有意な改善はなかったが, PEG 群におい 
て CRP (前 vs 後 $: 7.0 \pm 1.7 \mathrm{mg} / \mathrm{d} l$ vs $2.2 \pm 0.9 \mathrm{mg} / \mathrm{d} l$ $\mathrm{p}<0.05)$ の有意な改善を認めた。（3）経鼻力テ群にお いて Alb（前 vs 後: $3.3 \pm 0.1 \mathrm{mg} / \mathrm{d} l$ vs $3.0 \pm 0.1 \mathrm{mg} /$

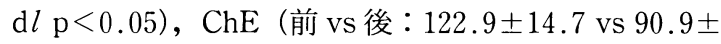
$12.2 \mathrm{p}<0.01 ）$ の有意な低下を示した。（4）両群間に 予後の差は認めなかったが, 嚥下性肺疾患による死亡 は, PEG 群 3 例と, 経鼻力テ群 8 例に比し少なかった。 （5） PEG の在宅管理アンケート調査では，簡便13例 (81.3\%)，まず簡便 3 例（18.7\%）と簡便性に問題は 認めず，在宅トラブルも，錠剤などによるチューブの 詰まり 3 例, 挿入部からの注入物の漏れ 3 例で大きな トラブルの発生はなかった。

結語：PEG 群にて與下性肺疾患の予防効果の可能 性が認められ, 在宅管理上の問題点も極めて少なく, 経口摂取不能患者の栄養摂取方法として更に普及が期 待される治療法と思われた。

\section{0. 剖検例で検索した老年者胃粘膜の加齢変化}

東京都老人医療センター・病理・外科

\section{江崎 行芳, 田久保海誉 \\ 沢辺 元司, 橋本 肇}

現在, 胃粘膜は加齢と共に段階的に萎縮が進み, 腸 上皮化生の程度が強くなる，とすることが一つの定説 となっている. しかし，これは手術された病的材料を 基にして出されたデー夕によったものである.

現実にはその生涯を通じて, 胃生検も胃切除も受け ない人が大半であろう。このため可能な限り生理的状 態に近い胃粘膜を観察する目的で，剖検症例を用いて 腫瘍や潰瘍など局在病変のない胃を「無病変胃」と定 め,これを病理組織学的に検討した。

対象は60歳台から90歳台まで男女20例ずつを無作為 に選出したものである.100歳台については最近までに 行われた男性 7 例と女性20例を対象とした.

これらを胃底腺萎縮の程度, 腸上皮化生の程度, 腺 境界の位置などの項目について, 各年台群・性別で比 較検討した。

その結果, いずれの項目においても加齢と共に変化 の強い症例の頻度が上昇し, 男性群の方が女性群より も高頻度となっていた。しかし，その程度はいずれも 手術材料による検索で規定された程のものでなく，各 年台群共に今まで報告されている頻度からはかなりの 隔たりがあった.100歳台であっても全く胃底腺の萎縮 がなく, 腸上皮化生の認められない症例が存在するの である。
加齢変化に関わる因子は主として線維組織や血管な どの間葉系であり，上皮ではないとする考え方が正し いと思われる.人は永く生きればそれだけ様々な病的 状態に遭遇する機会が増加する。それが変化として現 れたとしても，このことが「老化」と混同されるべき でない.

\section{1. 内視鏡的計測からみた高齢者胃潰瘍の特徵}

藤田保健衛生大学第二病院内科

西尾 浩志, 中澤 三郎

芳野 純治，若林 貴夫

ステレオ式ビデオスコープにて胃潰瘍の大きさ, 再 生上皮の進展速度を求め, 加齢と潰瘍の特徵について 検討した。

対象：ステレオ式ビデオスコープにて活動期から経 過観察の行えた胃潰瘍患者45例46病変で, 年齢は 24〜81歳 (平均年齢57.4歳) であった. ヒスタミン $\mathrm{H}_{2}$ 受容体拮抗薬 $\left(\mathrm{H}_{2} \mathrm{RA}\right)$ 内服症例は 29 病変, プロトンポ ンプ阻害薬 (PPI) 内服症例は11病変, 粘膜防御因子増 強剤（MPA）内服症例は 6 病変であった。

方法：ステレオ式ビデオスコープを用いて潰瘍底, 潰瘍領域（潰瘍底と再生上皮を含む領域）の面積を求 めた．再生上皮の長さは潰湟を円と見なすことで潰瘍 領域の面積に相当する円と潰瘍底の面積に相当する円 の半径の差から求め, 観察期間中に延びた再生上皮の 長さを観察期間で除した值とした。評価期間は再生上 皮が認められた時点から 8 週以内の最終観察まで，ま たは瘢痕化までとした。

成績：(1)活動期の潰瘍の大きさが計測できた46病変 で, 年齢と潰瘍底の大きさには正の相関が認められた。 (2) $\mathrm{H}_{2} \mathrm{RA}$ 投与群では, 治癒に 8 週以上要した潰瘍の活 動期の大きさはそれより早く治癒した潰瘍より明らか に大きかった $(\mathrm{p}<0.01)$. (3)再生上皮の進展速度は PPI 投与群の方が $\mathrm{H}_{2} \mathrm{RA}$ 投与群に比べて有意に良好 であったが, 両群とも再生上皮の進展速度は年齢や活 動期の潰瘍底の大きさと関係は認められなかった. (4) 潰瘍領域の収縮率は PPI および $\mathrm{H}_{2} \mathrm{RA}$ 投与群ともに 差は認められなかったが，PPI 投与群では潰瘍が大き いほど収縮率は良好になる傾向があった。年齢と潰瘍 領域の収縮率は両群ともに関係は認められなかった。

まとめ：加粭とともに潰瘍は大きくなる関係にあっ た。潰瘍の治瘜機転の主要因である再生上皮の進展速 度と潰瘍自体の収縮率については, 加齢および活動期 の潰瘍底の大きさと関係は認められず，潰瘍の大きさ 
が治癒期間に影響を及ぼすと考えられた。

\section{2. 老年者の胃・十二指腸潰瘍と炎の合併症}

札幌慈啓会病院内科

川原田 信，佐藤 保則

当院における65歳以上の老年者胃・十二指腸潰瘍の 頻度, その背景および合併症等について検討したので 報告する。

対象は当院に種々の疾病の治療のために入院した 65 歳以上の老年者 1,470 例で, そのうち胃・十二指腸潰瘍 は60例 (4.1\%：胃潰瘍50例，十二指腸潰瘍 10 例）にみ とめられた。その頻度は胃・十二指腸潰場とも女性に やや高い傾向がみとめられた。

胃潰瘍の発生部位は胃体〜噴門部24例, 胃角部10例, 前庭部20例と胃体〜噴門部潰瘍が48\%を占めた。また 潰瘍数は多発潰瘍 8 例, 単発潰瘍 42 例と多発潰瘍が 16\%を占め, 高位化, 多発化する傾向がみとめられた.

胃・十二指腸潰瘍の主訴では上腹部痛 22 例 (36.7\%), 吐血・下血 20 例 (33.3\%), 食欲不振など定型的消化器 症状の他に，全身倦怠感，動悸などいわゆる非定型的 消化器症状も $1 / 4$ の症例にみられた。

基礎疾患は骨 - 関節疾患, 肝・胆道疾患, 呼吸器疾 患など種々であったが, 骨・関節疾患, 肝・胆道疾患 を併せて全症例の $50 \%$ を占めた。骨・関節疾患, 胆石 症を含めた肝・胆道疾患は疼痛を伴うことも多く, こ れらのストレスあるいは使用された薬剤が潰場発生に 誘因を与えたものと思われる。

誘因としては NSAIDs 10例，ステロイド 5 例，スト レスを含む原因不明45例であった. NSAIDs が誘因と 考えられた十二指腸潰瘍 3 例のうち 1 例は吐血・下血 のため手術がなされ，またステロイドが誘因と考えら れた十二指腸潰瘍 2 例のうちの 1 例は穿孔性腹膜炎の ため死亡した。誘因が不明であった十二指腸潰瘍 5 例 のうち 1 例は大量の吐血・下血のために死亡した。誘 因がいずれであれ十二指腸潰瘍例で吐血・下血, 穿孔 など重症化し予後不良になる傾向がみとめられた。

\section{3. 長期嚥下障害患者の在宅療養の可能性について} 一経皮内視鏡的胃瘻造設術患者の長期検討から一

西崎病院内科 ${ }^{11}$, 琉球大学第二内科 ${ }^{21}$

$$
\begin{array}{lll}
\text { 山城 啓 }{ }^{1)} \text { 中田 } & \text { 安彦1) 大嶺 雅規 }{ }^{11} \\
\text { 名嘉 } & \text { 勝男 }{ }^{1)} \text { 高須 } & \text { 信行 }{ }^{2}
\end{array}
$$

目的：高齢化社会の進展に伴い経口摂取困難な寝た きり老人の医療施設への入院の増加が見られ, 医療費
高騰の要因の一つとも言われている，ところが経皮内 視鏡的胃㾞造設術 (以下 PEG と略す) の施行によりこ れらの老人に対する長期の栄養管理が容易となり，医 療施設より在宅療養への糸口になるのではないかと考 え PEG 施行例の短期及び長期合併症, 在宅期間につ いて検討した.

対象と方法：当院にて1989年11月から1994年11月ま でに施行された PEG の58症例（男性15例，女性43例） を対象とした。年齢は40歳から102歳 (平均83.5歳)ま での経口摂取困難な症例であり, 施行に伴う周術期 ( 1 週間以内), 短期 ( 1 力月以内) 及び慢性期合併症, PEG 後の生存期間, 退院症例数, 在宅日数等について分析 した。

結果：基礎疾患は老年痴呆 29 例, 脳血管障害後遺症 27例, 脳腫瘍 1 例, 外傷性精神病 1 例であった。周術 期合併症としては自己抜去 3 例, 腹膜炎 2 例, 皮下膿 瘍 1 例, 吐血 1 例がみられた。短期及び慢性期合併症 として最も多いのは嘔吐でありその他下痢, 胃瘦 チューブからの胃液流出があった。週間合併症発生率 では周術期が最も高く経過と共に発生頻度は減少し, また, 非在宅群に比べ在宅群が低值を示していた。ま た PEG 後1995年 3 月 20 日現在までの平均生存日数は 460.2 日，退院ができた症例は58例中19例 $(32.8 \%)$ で ありその平均在宅日数（老人ホーム，老人保健施設を 含む）は338.5日であった。

総括：高齢者人口が増加する現代社会において経口 搨取困難な寝たきり老人の在宅療養は高齢者医療にお いて大きな課題であるが今回の検討により, PEG 施行 によってこれらの在宅療養が可能になりつつあると考 えられた。

\section{4. 癌多発症候群としての Werner 症候群}

都立大塚病院リウマチ膠原病科

後藤 真

Werner 症候群は, 若年のうちから, 白内障, 白髪, 糖尿病, 皮膚硬化, 動脈硬化などの多くの老化徴候を 発症し, 平均年齢49歳で, 動脈硬化か悪性腫瘍で死亡 する遺伝性早老症である。これまで世界中で, 約 1,000 例, そのうち日本で, 約 800 例が確認され，そのうち 189 例の悪性腫瘍の合併が認められている．日本の症例で は，25例の軟部組織肉腫， 7 例の骨肉腫，20例の悪性 黒色腫，15例の髄膜腫を含む 83 例の非上皮性腫場と 65 例の癌腫で, 諸外国では, 7 例の軟部組織肉腫, 4 例 の骨肉腫， 7 例の髄膜腫を含む 26 例の非上皮性腫瘍と 
15例の癌腫を含む41例である，一般の悪性腫瘍の種類 の分布と大きく異なり，肉腫が圧倒的に多数を占めて いるのが特徴的である，日本人に多い，胃癌，肺癌は 稀であり，老人に多い前立腺癌は，諸外国の 1 例に認 められたにすぎない. 悪性腫瘍の種類の偏位に加えて, 腫湟の発生部位にも異常が目立つ。悪性黒色腫では, 5 例が鼻腔内に, 1 例は食道に発生し, 骨肉腫では, 眼窝や足趾の小骨, 滕蓋骨に発生する例が認められた。 悪性腫場の中での性比も, 髄膜腫は, 一般集団では, 女性優位であるが, Werner 症候群では, ほとんどが, 男性である。骨肉腫は一般的には, 思春期前の疾患で あるが, Werner 症候群では, 40歳以降にみられる.こ のように, Werner 症候群では, 一般集団と比べて, 悪 性腫㰾の種類, 発生年齢, 発生部位, 性比が著しく異 なる，さらに，同一の患者に， 5 重癌， 3 重癌を含む 重複癌の発生が, 22例あった。これまでWerner 症候 群は早老症としての側面が強調され, 悪性腫瘍は, そ の附随症状として扱われてきたが, その発生部位, 組 織型, 男女差, 年齢分布, どれをとってみても, 一般 集団とは, 大きく異なり, 本症候群は, 遺伝性癌多発 症候群として捉え直す必要がある。

\section{5. 老年者における胃癌と食道癌の手術成績の比較}

東京都老人医療センター外科

高橋 忠雄, 橋本 肇, 野呂 俊夫
日野 恭徳, 平島 得路, 黒岩厚二郎
白神 敏雄, 坂川 公一, 泉里 友文
山城 守也

老年者の胃癌と食道癌における手術の短期的および 長期的成績を比較検討した.

対象・方法：当センター外科における過去14年間の 胃癌手術511例（男304例，女207例）および食道癌手術 45例（男33例，女12例）を対象として手術死亡および 術後長期生存を比較検討した. 多重ロジスティックモ デル分析を用いて術後50日以内死亡（手術死亡）に対 する危険因子を，また Cox の比例ハザードモデル分析 を用いて術後長期生存に対する危険因子を推定し, 比 較検討した。分析に用いた因子は年齢・性別・癌特性 6 ・術式・術前併存症 6 ・術後合併症 5 ・死因である. また生存率の比較には generalized Wilcoxon test を 用いた。

成績：胃癌症例の平均年齢は $75.6 \pm 7.9$ 歳, 食道癌の 平均年齢は $72.6 \pm 6.3$ 歳で両群の間に有意の差はみら れなかった.手術死亡率は胃癌6.3\%, 食道癌13.3\%で,
食道癌の成績が有意に悪かった. 多重ロジスティック モデル分析を用いた手術死亡に対する有意の危険因子 として両群ともに第 1 位であったのは術後呼吸器系合 併症で, その相対危険度 (odds ratio) は発生なしに対 して発生ありは胃癌で15.1倍, 食道癌で32.5倍で, 食 道癌においてより深刻であった。 10 年生存率の比較で は胃癌 $28.8 \%$, 食道癌 $13.0 \%$ で胃癌が有意に成績がよ かった. Cox の比例ハザードモデル分析を用いた術後 長期生存に対する有意の危険因子として両群に共通で あったのは癌 Stage であった。

結語：老年者の胃癌と食道癌の手術成績を比較する と死亡率, 生存率ともに食道癌が悪かったが, 両群に おいて共通するのは術後呼吸器合併症が手術死亡に最 も寄与する危険因子であり, 術後十分に呼吸器の監視 を行いこの合併症の発生の予防に注意しなければなら ない. また術後長期生存の危険因子はともに癌 Stage であったことは, 老年者においても術前併存症のリス クを越えても癌の早期発見, 早期治療が予後に大きな 影響を与えることを示している。

\section{6. 高齢者胃癌一非手術例についての臨床的, 病理 学的検討}

東京都老人医療センター外科, *内視鏡, **病理

橋本 肇, 高橋 忠雄
紀 健二*, 江崎 行芳**

高齢者の胃癌については年齢にかかわらず手術適応 が拡大され積極的に手術されるようになった. 当院に おいても近年急速に 80 歳以上の高齢者の胃癌の手術が 増加している. しかし未だ高齢者では手術されていな い症例も少なくないのが現実である。

目的：高齢者胃癌の非手術例の実態を明らかにし, その対策を考える.

症例と方法: 過去 8 年間に死亡し, 胃癌がありなが ら手術されていない症例は158例で, 男96名, 女62名で あった.これを前期老年者（60～74歳） 38名, 中期老 年者（75〜84歳） 77 名, 後期老年者 (85歳〜) 43 名に 分け, 非手術の理由, 癌が診断されてからの生存期間, 併存疾患, 死因, 病理所見などについて検討した。

結果：早期癌, 進行癌はそれぞれが前期で13例, 25 例, 中期で20例, 57例, 後期で14例, 29例であった。 非手術の理由は進行癌では肝転移など胃癌の進展が前 期で $76.8 \%$, 中期で $52.6 \%$, 後期で $37.9 \%$ と多く, 早 期癌では他疾患, 前期では他藏器悪性疾患, 中期では 
他臓器悪性疾患, 痴呆, 肝硬変, 後期では他臓器悪性 疾患, 全身衰弱, 痴呆, 呼吸器疾患などが多かった。 また拒否は前期で 6 例 $(15.8 \%)$ ，中期で15 (19.5\%), 後期で10（23.3\%）であった。生存期間は早期癌では 2 年半までは後期が良いが，総計で 1 年で $50.7 \% ， 2$ 年で $24.8 \% ， 3$ 年で $15.2 \% ， 4$ 年で $7.85 \%$ であった. 進行癌では年歯差が見られず，合計で1年で $9.6 \% ， 2$ 年で $1.7 \%$ であった. 死因は早期癌では他疾患が, 進行 癌では胃癌自体が原因となるものが多かった，他疾患 としては前期の早期癌では他臟器悪性疾患が, 中期の 早期癌では呼吸器疾患が, 後期では呼吸器疾患が多く 見られた. 進行癌の他疾患では呼吸器疾患が主なもの であった。

結論：高齢者の胃癌ではいまだ非常に進行した状態 で発見され非手術となる例が少なくない. 早期発見の 必要性が考えられた。

\section{7. 地域住民における悪性腫瘍死亡率とその危険因} 子の時代的変化 : 久山町研究

九州大第二内科

清原 裕, 加藤 功, 岩本 廣満
中山 敬三, 清水 治樹, 谷崎 弓裕
大村 隆夫, 上田 一雄, 藤島 正敏

目的：福岡県久山町における長期追跡調査の成績を もとに, 悪性腫瘍死亡率とその危険因子の時代的変化 を検討した。

対象と方法：1961年に設定した40歳以上の前期第 1 集団1,621名と,1974年に設定した同年齢の後期第 2 集 団2,053名を対象とし，それぞれ13年間追跡した。追跡 期間中に両集団とも440名が死亡し，第 1 集団では361 例（82\%）を，第 2 集団では379例（86\%）を剖検し， 死因を検討した. 第 1 集団では 102 例を，第 2 集団では 133例を悪性腫瘍死と診断した. 各集団の追跡開始時に 収集した血清コレステロール, 耐糖能異常, BMI, 飲 酒 - 喫煙習慣, 血圧値, 心電図異常を危険因子の分析 に用いた。

結果：全悪性腫瘍死亡率（対千人年）は，第 1 集団 の5.5から第 2 集団の 4.9 にわずかに減少した。部位別 にみると, 胃癌死亡率は第 1 集団 2.2 から第 2 集団 1.3 へ有意に減少した. 全悪性腫瘍死亡の危除因子を年齢 調整して検討すると，第 1 集団では男女とも喫煙者の リスクは非喫煙者と比べ 2 倍有意に高かった。一方，

第 2 集団では喫煙のリスクが減少し, 男性で耐糖能異 常が全悪性腫瘍の有意な危険因子となった。悪性腫瘍 の危険因子を腫瘍別にみると, 喫煙は, 両集団で肺癌
の有意な危険因子となった。また，喫煙は第 1 集団で 胃癌の有意な危険因子となったが，第 2 集団ではその リスクが減少した，悪性腫瘍を肝・膵癌とその他の癌 の 2 群に分けて，耐糖能異常との関係を検討した。第 1 集団の男性では，耐糖能異常と悪性腫瘍との間に明 らかな関係は認めなかったが，第 2 集団の男性では耐 糖能異常はその他の腫瘍の有意な危険因子となった。 一方，両集団の女性において，耐糖能異常は肝・膵癌 の有意な危険因子となったが，その他の腫瘍と関連し なかった。

結論：久山町では，悪性腫瘍死亡率に時代的変化は なかったが, 近年, 悪性腫瘍に対する喫煙の影響が減 少し, 代わりに耐糖能異常がそのリスクとして登場し た.

\section{8. 老年期痴呆の脳波一周波数解析を用いた検討一 名古屋市総合リハビリテーションセンター神 経内科}

蒲澤 秀洋, 松原 充隆 日比野敬明, 深川 和利

目的：老年期痴呆の脳波は $\alpha$ 波の減少と $\delta$ 波ある いは $\theta$ 波の増加が一般的である. 今回, 老年期疾呆の 脳波の特徴を明らかにする目的で高速フーリエ変換 (FFT) によって脳波の定量化を行い正常群と比較検 討した。

対象および方法：対象はアルツハイマー型老年痴呆 (SDAT) 15例と正常者30例。脳波の測定は安静覚醒閉 眼時に行い, 脳波を5.12秒 $\mathrm{AD}$ 変換し, 5 回平均加算 して取り込みを行った。電極は国際電極基準法に従い, F7, F8, FP1，FP2を除く15部位とし, 両側短絡耳架 を基準電極とした．周波数解析・画像処理は Nicolet

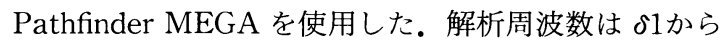
$\beta 3$ の 9 帯域に分類し Power 值と\%Power 值を求め た。

結果：優位に出現する周波数帯は正常群では $\alpha 2$ 帯 域, 老年痴呆群では $\theta 2$ 帯域であった。 また, 痴呆群で は各周波数帯域において左右差がある傾向であった。 さらに，各15部位における正常群と痴呆群の比較では $\delta \sim \theta 2$ 帯域の\%Power 值が痴呆群の全測定部位で有意 に高く， $\alpha 1$ 帯域では有意差がみられなかったものの $\alpha 2 \sim \beta 3$ 帯域では痴呆群で低率の傾向がみられた. 可能 な症例では言語負荷を実施した。

老年医学的意義：老年期疾呆の脳波で周波数解析を 行うことにより脳機能低下を示す部位, 脳機能低下の 程度が推測される可能性が考えられた。 
309. 老年期精神疾患における随伴陰性変動 $(\mathrm{CNV})$ について

大阪大精神科

角 典哲, 山畑 清, 深江 伸子

岡山 孝敬, 南野 壽重, 西村 健 大阪府立病院精神科藤本修

大阪府立こころの健康センター

花谷 隆志，太田 義隆

目的：老年期のうつ病, 精神分裂病およびアルツハ イマー型痴呆につき, 情報処理課題下に扔ける注意・ 集中機能を客観的に検討するため, 随伴陰性変動 （CNV）を記録し，健康老人の成績と比較検討した。

対象と方法：対象は, 55歳以後に発症し, DSM-IIIR の大うつ病の基準を充たす，老年期うつ病 25 名（DEP 群: 68.8歳)，20４5歳に発症し, 現在60歳以上の精神 分裂病 (残遺型) 21名 (SCH 群: 64.6歳) おょび NINCDS-ADRDA の probable Alzheimer 痴呆の基 準を充たし, $\mathrm{N}$ 式精神機能検査の成績が軽度疾呆の 20 名 (DAT 群: 72.3歳) で, 精神神経学的に異常のない 健康老人 39 名（健康群：68.5歳）を対照群とした。

CNV は警告刺激（S1）と，その1.5秒後に命令刺激 (S2)を与え，1）S2後ボタン押し反応を行う (CNV-1) と，2）S2刺激を無視する(CNV-2)を，1)，2）の順で 施行し, その際の脳波をそれぞれ15回平均加算して記 録した. CNV-1について, CNV 振幅, 命令刺激後陰性 変動(PINV)の振幅および解消時間, CNV-2について, $\mathrm{CNV}$ 振幅を測定し, 両 $\mathrm{CNV}$ 振幅より, その減衰率を 算出した.

結果：健康群, DEP 群, SCH 群および DAT 群の CNV-1振幅は，それぞれ $14.4,17.2,8.0$ および12.4 $\mu \mathrm{V}$ であり, 健康群に比べ, SCH 群では有意に低振幅で あった $(\mathrm{p}<0.001)$.また, PINV 振幅は, 4 群間に有 意な差異はみられなかったが, PINV の解消時間は, 健康群, DEP 群, SCH 群およびDAT 群においてそれ ぞれ，695.2，1，183.2，912.4および1,022.9msecであ り, DEP 群では有意な延長が認められた $(\mathrm{p}<0.05)$. CNV-2における減衰率は，4群においてそれぞれ， $58.6 ， 58.8 ， 36.3$ おび47.0\%であり， $\mathrm{SCH}$ 群（p< $0.01)$ および DAT 群（p<0.05）で有意に低い值を示 した.

考察：CNV-1の結果から, 精神分裂病では注意集中 機能が低下し, うつ病では, 課題終了後に興奮が持続 することが考えられる。一方, CNV-2の結果より, 精 神分裂病およびアルツハイマー型痴呆では, 課題条件 変更に伴う遂行方策の再構成が困難であることが推測
された。

310. 老年期痴呆における神経生理学的検查と知的機 能, 局所脳血流分布の関連（I）：P300を指標として 大阪大精神科

金井 正光，原田 和佳, 速水 大輔

角 典哲, 小川ひとみ, 田口 智己

南野 壽重, 西村 健

大阪府立病院精神科藤本修

大阪府立こころの健康センター

太田 義隆

はじめに：我々はこれまで健康老人および老年期痴 呆疾患から, 体性感覚誘発電位 (SER), 事象関連電位 （P300）を記録し，これらの神経生理学的検査が中枢神 経機能や精神機能の加齢変化の客観的評価および生理 的老化と病的老化の鑑別に有用であることを報告して きた. 今回，老年期疾呆疾患を刘象として，P $300 ， N$ 式精神機能検查 ( $\mathrm{N}$ 式), IMP-SPECT を実施し, これ らの結果を比較検討したので報告する.

対象と方法：対照は,アルツハイマー型痴呆 (DAT) 15名（平均69歳）と脳血管性痴呆 (CVD) 18名（平均 66歳) であり, 対照群は精神神経学的に問題のない健 常者22名（平均64歳）である. 知的機能の評価には, $\mathrm{N}$ 式を用い, P300は聴覚刺激を用いた odd-ball 課題 下で記録した. IMP-SPECTによる局所脳血流 (rCBF)の評価は脳内18力所に関心領域 $(\mathrm{ROI})$ を設け, それぞれの放射能活性を小脳半球に対する比で求め た。

結果と考察：DAT及びCVDの $\mathrm{N}$ 式の平均得点 は, $71 \pm 9$ 点, $70 \pm 13$ 点であった. DAT 及び CVD と もに対照群と比べて, P300の P200, N200, P300頂点 潜時が有意に延長していた.DAT はすべての ROI で, CVD は左後頭葉を除くすべての ROI で対照と比べて 有意な RI-uptake 低下を認めた. P300, N 式, SPECT の成績の関連について検討すると,DAT では, P300頂 点潜時と前頭葉の $\mathrm{rCBF}$ との間に有意な負の相関を 認めたが，P300頂点潜時と $\mathrm{N}$ 式の得点の間に相関を 認めなかった. CVD では，P300頂点潜時と N 式の得 点の間に負の相関を認めたが, $\mathrm{P} 300$ 頂点潜時と $\mathrm{rCBF}$ との間には相関を認めなかった。

P300, SPECT の結果及び N 式の成績を比較検討す ることは, DAT, CVD に抢ける精神機能と脳血流の関 連を明らかにし, 痴呆性疾患の病態生理を把握するの に有用であると考えられた。 


\section{1. 老年期痴呆における神経生理学的検査と知的機} 能, 局所脳血流分布の関連 (II)：SER を指標として 大阪大精神 ${ }^{1}$, 大阪府立病院精神 ${ }^{2}$, 大阪府立 こころの健康総合センター ${ }^{3)}$, 住友病院 ${ }^{4)}$

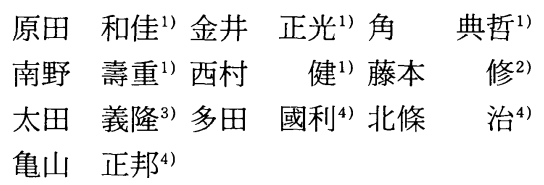

はじめに: 我々は以前, 左右両側刺激時の体性感覚 誘発電位（SER）の頂点潜時を検討することが，老年 期痴呆疾患の鑑別に有用であることを報告した。今回, 老年期痴呆疾患 (DAT, CVD) を対象として, SER, IMP-SPECT， $\mathrm{N}$ 式精神機能検査（ $\mathrm{N}$ 式）を実施し, これらの結果を比較検討したので報告する.

対象と方法: 対象は, アルツハイマー型痴呆 (DAT) 15名（平均69歳）と脳血管性痴呆 (CVD) 18名（平均 66歳) であり，対照群は精神神経学的に問類のない健 常者22名 (平均64歳) である. SER の記録は, 手掌部 に機械的刺激を与えた時に生じる脳の反応電位を対側 知覚領より50回平均加算して得た。局所脳血流 (rCBF) の評価は脳内18力所に関心領域 (ROI) を設け, それぞれの放射能活性を小脸半球に対する比で求め た。

結果と考察：DAT 及びCVDの $\mathrm{N}$ 式の平均得点は

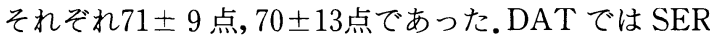
の P3，N3頂点潜時が，CVD では N2，P3，N3頂点潜 時が対照群に比べて有意に延長していた. SER の各頂 点潜時の左右差を検討したところ, CVD では N2, P3， N3の各頂点で対照群と比べて有意な左右差が認めら れたが, DATでは明らかな左右差を認めなかった。次 に SPECTにおいて各 ROI の左右差をみると，DAT では前頭葉，側頭葉，頭頂葉で，CVD では前頭葉，側 頭葉, 視床で有意な左右差が認められた.SER の N3頂 点潜時と $\mathrm{rCBF}$ との関連を両群それぞれ比較検討し たところ，CVDにおいてN3頂点潜時の左右差と基底 核, 視床の $\mathrm{rCBF}$ の左右差との間に有意な正の相関が 認められたが，DATでは相関はみられなかった。一 方，N3頂点潜時と $\mathrm{N}$ 式の成績との間には両群とも有 意な相関はみられなかった。

以上より DAT，CVD の鑑別診断の指標として有用 な SER の左右差は, 基底核, 視床などの皮質下の病変 と関連を有することが推測された。今後さらに症例を 増やし, SER の左右差の発生機序について検討を加え たい.
312. アルツハイマー型痴呆の画像所見一早期発症と 晚期発症による比較検討一

東京医科大学老年科

羽生 春夫, 新井 久之, 阿部 晋衛
中野 正剛, 岩本 俊彦, 高崎 優

目的：初老期発症のアルツハイマー病と老年期発症 のアルツハイマー型老年痴呆との異同については，こ れまで多くの議論がなされ，一定の結論は得られてい ない. 今回，両者の病態に相違がみられるか否かを明 らかにするため，画像所見を比較検討した。

方法：脳血管障害の危険因子を有さないアルツハイ マー型痴呆患者のうち65歳未満の早期発症型（earlyonset $\mathrm{AD}, \mathrm{EAD}$ ) 17例と晚期発症型 (late-onset $\mathrm{AD}$, LAD）30例を対象に，SPECTによる脳血流低下所見 と MRIによる深部白質病変, 萎縮性変化について比 較検討した。

結果：SPECT による側頭頭頂葉の血流低下の程度 TP ratio (RI カウント数による対小脳比) は, LAD 群 に比し EAD 群で有意な低下が認められた。また定性 的評価による血流低下範囲は, LAD 群で側頭頭頂葉以 外の広範な領域にも及び，非定型的な脳血流分布パ ターンが多く認められた. MRIによる深部白質病変 (PVH と WMH)の比較では, PVH は両者で相違を認 めなかったが，WMH の程度は LAD 群で有意に大と なった．萎縮性変化 (皮質萎縮 $\mathrm{CA}$ と脳室拡大 $\mathrm{VE}$ ) の 比較では，VEに相違を認めなかったが，CA は LAD 群で有意に大となった.さらに, 非定型的な SPECT 所 見を示した患者ではCA の程度が有意に大となった。

以上より, LAD 群では脳血流低下所見はより軽度か つ非定型的であり, MRI 所見についても加齢に伴う細 小血管病変による深部白質病変や生理的な脳萎縮など の修飾を受け，このような画像所見の相違は大脳皮質 における病理学的変性が EAD 群とは異なるためと推 測された。

老年医学的意義 : アルツハイマー型痴呆は, 発症年 齢の違いにより画像的にも種々の相違がみられ, 病態 の多様性が示唆された. 特に, 老年期発症例では老化 に伴う種々の変化の修飾を受け，診断や病態の評価に 際して留意すべきである。

\section{3. 高齢者痴呆群と初老期痴呆群の ${ }^{123} I-I M P$ 脳} SPECT 所見（一パターン分類によるー）

東京都老人医療センター核医学診断科 間島 寧興，川上 睦美，山田 英夫 


\section{岸野 智則, 前田 茂, 丹野 宗彦 千葉一夫 \\ 同 精神科 小山 恵子 \\ 東京慈恵会医科大学泌尿器科

$$
\text { 三木 健太, 大石 幸彦 }
$$

目的：痴呆疾患の病態解明において, 脳血流画像お よび脳機能画像は必要欠くべからずな情報である。し かし, 現在の臨床の現場において, 簡便で侵襲性の少 ない検査である ${ }^{123}$ I-IMP脳 SPECT におけるデータ は, 定量性がそしく，特に脳機能画像として有用に使 用されていないのが現状である。このため，脳血流・ 脳機能画像デー夕を有効かつ簡便に使用する方法を検 討し，臨床例に応用し検討したので報告する。

方法：今回の検討において，画像データの解析を明 瞭にするため, 対象は, MRI 画像にて明らかな病的脳 萎縮変化が少ない, 高齢者痴呆群（75歳以上）と初老 期痴呆群（50〜 60歳）の二群に関して比較検討した。 方法は, I-123-IMP (222MBq) を静注し，30分後（早 期像）と 4 時間後 (後期像) にSPECTを施行し, 画 像データを作製した.今回の検討は, 早期画像と後期 画像によるパターン分類にておこなった。早期画像と 比し, 後期画像の RI activity が減少する正常および正 常に近い機能を示す減少型, RI activity が同じで中程 度の機能低下を示す平行型, RI activity が増加し極度 の機能低下を示す増加型に分類した。

結果：初老期痴呆群においては, 隇少型が $95 \%$, 平 行型が $5 \%$, 増加型 $0 \%$ であった。高齢者痴呆群では 減少型 $50 \%$, 平行型 $30 \%$, 増加型 $20 \%$ であった。この 二群のパターン分類分布変化, すなわち高齢者群に異 常パターンが増加していることより, 痴呆病態の進行 を把握できる可能性が考えられた。

老年医学的意義 : 現在, 痴呆および脳機能を定量的 に把握することは困難である.しかし，本法を使用す ることより,比較可能な定量診断が可能と考えられる. さらに, 簡便さより, 臨床の現場での有用性も高いと 考えられる。

\section{4. 高齢者の剖検脳における組織学的老年性変化と 痴呆重症度の関連}

浴風会病院内科

亀田 典佳, 吉田 亮一, 大友 英一

目的：神経原線維変化 (NFT) と老人斑 (SP) は, 病理学的に代表的な老年性変化であり,アルツハイ マー型老年疾呆の重要な所見である。過去において, これらの変化と痴呆の関係を検討した研究はあるが,
その関係は明らかといいがたい. 我々は，老年変化と 痴呆の関係を明らかにするために, NFT, SP を定量的 に分析し臨床症状との対応を行った。

対象：1983.1.1.〜1995.2.27の連続剖検例1,059 例のうち, 脳腫場, 硬膜下血腫がなく, その割面で肉 眼的に梗塞巣や, 出血巣を認めず, 神経病理学的に PD, SMON, PSP, SND, SDS, MSA, CJD, GSS と診断された症例と, 臨床的に Kleinfelter 症候群, 肝 性脳症と診断された症例を除外した142例（平均年齢 $84.3 \pm 0.7$ 歳) を対象にした。

方法: 脳はホルマリン固定後, 前額断し乳頭体の後 方 $1 \mathrm{~cm}$ のスライスの側頭葉-島部の methenamineBodian 染色標本を作製, NFT と SP の数を計数した。 臨床症状は臨床記録を検討し, 痴呆の有無と痴呆の罹 病期間, 発症年齢を得, その程度を(一), mild, moderate, severe の 4 段階に分類し, また CDR で点数化し た.

結果：疾呆は発症年齢が早いと, 罹病期間が長い重 症例が増え, 高齿発症では罹病期間が短い軽症例が多 かった. SP はNFTに先んじて増加し, NFT は後か ら増加すると考えられ, NFT の増加で知呆の重症例 が増えると考えられた．SPをほとんど有しない症例 群ではNFT は加齢とともに増加する傾向がみられ た。

老年学的意義：アルツハイマー型老年痴呆は最終的 に病理診断によるが, 病理診断の確固たる基準はまだ あるとはいえない. 本研究でNFTに先行して増加す るSP の重要性を再確認した。

\section{5. アルツハイマー病リン酸化タウのリン酸化部位} 大阪大学医学部精神医学教室

以倉 康充, 工藤 喬
武田 雅俊, 西村 健

アルツハイマー病脳でみられる過剩にリン酸化され たタウ蛋白について, より重要と考えられるリン酸化 部位を検索する目的で部位別にリン酸化夕ウの定量を 行った. Radioimmunoslot-blot 法により，アルツハイ マー病脳側頭葉皮質より作製したホモジネートおよび その $100,000 \times \mathrm{g}$ 上清中のリン酸化夕ウ量を, 一次抗体 として Tau-1 (Ser199，202を認識) と PHF-1 (リン酸 化されたSer396を認識) を用いて検出し比較検討し た。その結果，ホモジネートでは Tau-1部位がリン酸 化されたタウはPHF-1部位の約 2 倍存在し, 上清では 逆にPHF-1部位がリン酸化されたタウが Tau-1部位 の約 8 倍存在した.したがって, PHF タウと可溶性リ 
ン酸化タウとの間にみられるこうしたリン酸化部位の 優位性の違いは, リン酸化夕ウが不溶化していく過程 において何らかの意味を持つものと考えられる.

\section{6. アルツハイマー病脳におけるタウ量の変化とそ のリン酸化について}

大阪大精神科

\section{工藤 喬，以倉 康充 武田 雅俊，西村 健}

アルツハイマー病 $(\mathrm{AD})$ 脳においてタウ蛋白は過度 にリン酸化を受けている。我々はこれまでに $\mathrm{AD}$ の夕 ウは部位によりリン酸化の程度が違うことを示し，よ り高度にリン酸化されている部位が病理過程に重要で あると考えてきた。一方, $\mathrm{AD}$ 脳や脳脊髄液では全夕ウ 量が上昇していることが指摘されている．今回我々は $\mathrm{AD}$ 脳でSer199・202とSer396のリン酸化の比率と全 タウ量の相関を検討した. 15例の $\mathrm{AD}$ 側頭葉を検討し たところ, 全タウ量とSer199・202のリン酸化が全タウ 量上昇に有意に相関することが示された. Ser199・202 のリン酸化が夕ウの代謝に影響することが示された.

\section{7. アルコールの脳障害}

\section{東北大学医学部老人科}

松崎 祥昭, 五十嵐康一

丸山 悠司，佐々木英忠

アルコール捸取の度が過ぎると痴呆症になることは 古くより知られているが，そのメカニズムとしては不 明である。本研究においては，ラットにアルコールを 搨取させ，脳内アセチルコリン量を測定すると共に， 認知機能を測定しアルコールの脳障害をみた。

生後 4 週目のラットを 2 群に分け, 一方はアルコー ル；15\%の日本酒を朝 $8 ： 00$ 夜 $6 ： 00$ まで自由摂取 させた。それ以外は水を飲ませた。他群は常に水を飲 ませた。

期間は24週間とした。24週目にアルコール中止 2 日 後に明暗箱にて認知機能をテストした，更に，5 日後 に脳アセチルコリン量を測定した。

結果は，アルコール摂取群では非アルコール群に比 ベて, 脳内アセチルコリン量は低下していた。しかし, 認知機能はわずかに低いのみで両群間に差はなかっ た。

以上の成績より，アルコール摂取により脳アセチル コリン代謝障害が生じ, 脳アセチルコリン量の低下が 生じることが証明された。しかし認知機能の低下まで は至らなかったが, この理由として, 急性期のアルコー
ル血中濃度は $50 \sim 100 \mathrm{mg} / \mathrm{m} l$ と低いためであるかも しれなかった。

慢性のアルコール捸取は, 例え急性期のアルコール 症状がなくとも脳障害をもたらす可能性が示唆され た.

\section{Frontal Lobe Degeneration の臨床病理学的} 検討

都多摩老人医療センター神経内科

$$
\text { 原 広一郎, 濱本 真 }
$$

同 精神科 大坪 孝一, 宮崎 徳蔵

同 臨床病理科 田中 邦明 都監察医務院病理 伊藤 雄二 吉村 正博

目的：臨床的に Frontal Lobe Degeneration (FLD) と診断された 3 症例について病理学的に検討した。ま た，当院での剖検例における FLD の出現率について 検討した。

対象：当院連続剖検症例804例中, 臨床的に痴呆 (DSM-IIIR における mild dementia 以上) と診断され たものは287例，その中で脳 SPECT 施行例106例を対 象とした。

方法：SPECT で, Starkstein らの報告と同様の前 頭側頭葉血流低下を認め, 血管性痴呆, アルツハイマー 型老年痴呆と異なる pattern を呈し，なおかつ前頭葉 症状を示し臨床的に FLD と診断されたものについて 検討した。

結果：SPECT を施行した106例中，FLD と考えら れたものは 3 例であった。初発年齢は50，60，80歳と 広範囲に亘っていた。 1 例のみ家族性. 初発症状は 3 例とも感情・性格変化で, 全経過はそれぞれ 7 年, 7 年， 4 年であった。 3 例とも頭部 CT にて前頭側頭葉 萎縮, SPECT にて前頭葉内側面, 側頭葉前部の血流低 下を認めた．脳波は 2 例が正常，1例は基礎律動の軽 度徐波化を示した。神経病理学的所見はそれぞれ側頭 一前頭型非定型的ピック病, 非定型的 SDAT, ビンス ワンガー型白質脳症であり，このうち非定型的ピック 病の症例が Brun らのいう Frontal Lobe Degeneration of non-Alzheimer type の近緑疾患と考えられ た.

考察：今回の検討において FLD の頻度は3/106例 (2.8\%) となり, $10 \%$ にみられるという Brun らの報告 や, 変性痴呆の中では $\mathrm{AD}: \mathrm{FLD}=4 ： 1$ といった欧 米の報告に比して低かった。 